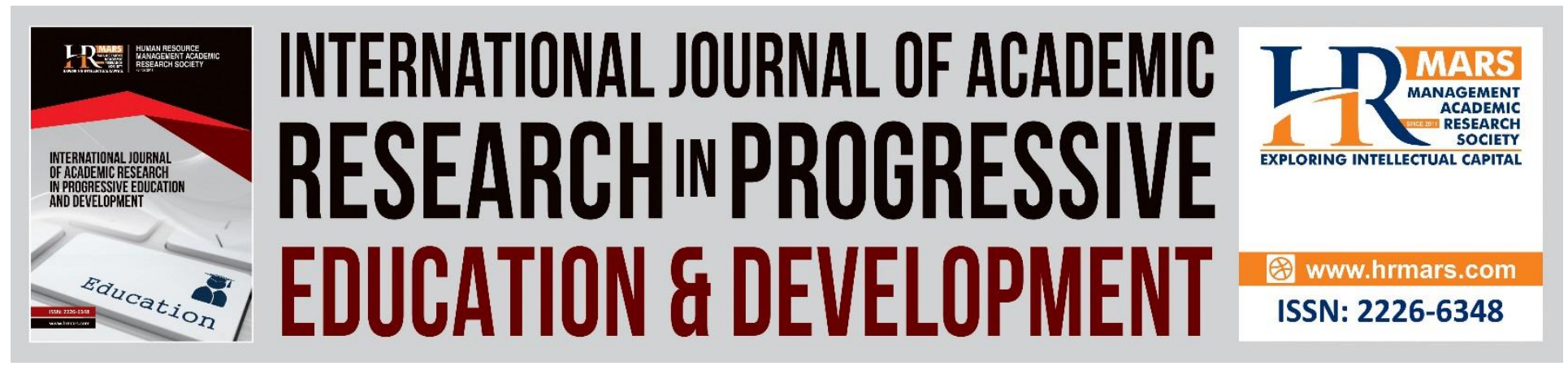

\title{
Vocational Education and Training for Young Offenders in Juvenile Approved Schools
}

Nazirah Hassan \& Muhammad Amirul Aidil Rosly

To Link this Article: http://dx.doi.org/10.6007/IJARPED/v10-i1/9620

DOI:10.6007/IJARPED/v10-i1/9620

Received: 07 January 2021, Revised: 04 February 2021, Accepted: 27 February 2021

Published Online: 20 March 2021

In-Text Citation: (Hassan \& Rosly, 2021)

To Cite this Article: Hassan, N., \& Rosly, M. A. A. (2021). Vocational Education and Training for Young Offenders in Juvenile Approved Schools. International Journal of Academic Research in Progressive Education and Development, 10(1), 642-650.

Copyright: (C) 2021 The Author(s)

Published by Human Resource Management Academic Research Society (www.hrmars.com)

This article is published under the Creative Commons Attribution (CC BY 4.0) license. Anyone may reproduce, distribute, translate and create derivative works of this article (for both commercial and non-commercial purposes), subject to full attribution to the original publication and authors. The full terms of this license may be seen at: http://creativecommons.org/licences/by/4.0/legalcode

Vol. 10(1) 2021, Pg. 642 - 650

http://hrmars.com/index.php/pages/detail/IJARPED

JOURNAL HOMEPAGE

Full Terms \& Conditions of access and use can be found at http://hrmars.com/index.php/pages/detail/publication-ethics 


\title{
LR \\ INTERNATIONAL JOURNAL OF ACADEMIC \\ RESEARCHINPROGRESSIVE \\ EDUCATION \& DEVELOPMENT

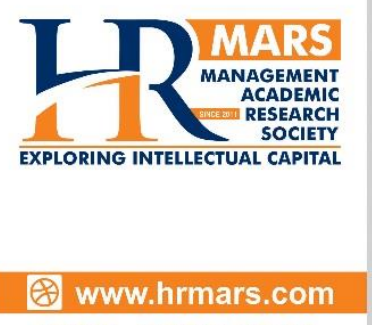 \\ ISSN: 2226-6348 \\ Vocational Education and Training for Young Offenders in Juvenile Approved Schools
}

\author{
Nazirah Hassan \& Muhammad Amirul Aidil Rosly \\ Social Work Program, Centre for Research in Psychology and Human Well-being, Faculty of \\ Social Sciences \& Humanities, The National University of Malaysia, 43600 Bangi Selangor, \\ Malaysia. \\ Email: nazirah@ukm.edu.my
}

\begin{abstract}
Vocational education and training is an important component for rehabilitating young offenders in juvenile approved schools. It provides offenders with technical skills and employment opportunities that can reduce the risk of reoffending and increase successful social reintegration into society. This study explores the potential benefits of vocational education and training programs for young offenders. Qualitative interviews were carried out with 16 young offenders comprising both male and female participants from two juvenile approved schools in Malaysia. The findings identify four main benefits of vocational education for young offenders, including positive adjustment, rehabilitative effects, positive transition to society and improve self-esteem. Young offenders also identify these benefits in reducing reoffending and improving their chances of successful community reintegration. This study has implications on evaluation of vocational education programs and policy improvements in juvenile approved schools.

Keywords: Vocational Training, Juvenile Education, Juvenile Intervention, Juvenile Offenders, Correctional Facilities.

\section{Introduction}

The involvement of young people in crime is viewed as a social problem of great concern. In 2017 and 2018, Malaysia reported more than 5200 crime cases involving young offenders, and about 13 per cent of the cases were repeated offence (Department of Statistics Malaysia, 2019). Offences related to property are prevalent especially to male young offenders, including theft, housebreaking, burglary, vehicle theft, robbery, and dealing in stolen property. Convicted young offenders may be placed either in probation hostels, Juvenile Rehabilitation Centres or Juvenile Approved Schools, depending upon the age and the seriousness of their offences. The administration of juvenile approved school is guided by the Child Act 2001 and the Approved School Regulation 1981. Under these regulations, all young people have to be treated with adequate care and protection. That is, every child deprived of liberty must be treated with humanity and respect and in a manner that takes into account their needs, including needs
\end{abstract}


related to education, vocational skills, meaningful treatments, accommodations, and contact with family members (UNICEF, 2013). The head of the institution, alongside a team of social workers, is responsible for providing children's daily needs as well delivering comprehensive treatment and care to the children. They work closely and directly with the children, and they are responsible for creating a positive institutional environment by not only delivering the service but also through the development of supportive professional relationships with the children. The administration of each institution is assisted by a Board of Visitors appointed by the Minister of Social Welfare for a term of two to three years. Their participation represents the valuable contributions that the lay community can make in the treatment of juvenile delinquents (Bee, 2002). Both Prison and Welfare Department facilities employ a mix of professionals. While all staff members undergo a basic induction training program, none have received specialized training on managing young people in conflict with the law (UNICEF, 2013). Each institution has responsibility for the children from the time of arrest or referral until the release and reintegration of the young people back into society. Treatments provided in the institution are geared towards preparing the young people from the very instant they step into the school for their ultimate return to their family and society. In both Prison and Welfare Department facilities, the approach to rehabilitation is based largely on a standardized regime of discipline, religious instruction and vocational training (UNICEF, 2013). In Malaysia, juvenile justice institutions are also called approved schools. In this regard, these facilities are designed to look less like prison and more like the school. In fact, the programmes offered in the institution focus on enhancing education and vocational skills. Some institutions offer formalised schooling in-house (UNICEF, 2013). In Malaysia, each institution includes between five to 20 hectares of space encircled by either barbed wire fence or stone walls. Institutional facilities include administrative buildings, dormitories, room/cell for detention, workshops for vocational training, classes for academic studies, a library, a dining hall, a bakery, an indoor hall, a seminar room, a space for outdoor activities, and other equipment (e.g. computer room, a gymnasium, a TV room, a wash room, a washing area, and a prayer hall (Bee, 2002).

Education and vocational training are an important component of rehabilitation in the institution (Azam et al, 2021; Esa, Salleh \& Mohamad, 2017). Young people who are still receiving schooling are allowed to continue their formal education. They are allowed to continue schooling outside the institution, where they will get formal education in conventional schools with other children. Nonetheless, they have to live in the institution throughout their sentencing period. Institutional staff members are responsible for fetching them to and from school. Formal education is also provided in some institutions (especially female institutions) at primary and secondary level. Young people who have dropped out of school and have not attained any education/formal qualifications are encouraged to attend literacy classes, where they learn reading, writing and counting (also called $3 \mathrm{M}$ ). They are also encouraged to participate in vocational training. For boys, vocational training involves carpentry, motor mechanics, welding, electrical wiring, handcraft, compressing bricks and bricklaying, bakery, plumbing and agriculture (Bee, 2002). For girls, training includes bakery, tailoring, embroidery, handcraft and culinary (Bee, 2002). Vocational training is provided in the hope that young people will be able to secure employment based on the skills acquired after their release from the institution. In fact, some institutions offer 
certificate-based vocational training programs that provide young people with the qualifications necessary to get a job after they are released (UNICEF, 2013). Overall, by participating in these programmes, young people are afforded the opportunity to develop not only their competitive skills, but also to change their thinking, goals and values. Nonetheless, very few young people actually benefit from such education and vocational training programs in the institution (UNICEF, 2013). In fact, many young people in institutions have never received appropriate treatment for reducing offending behaviours. This is, perhaps, affected by the limited number of trained and skilled practitioners available in the institution (UNICEF, 2013). In accordance with the United Nations Convention on the Rights for Children (UNCRC), the Child Act 2001 has emphasized the goals of treatment and rehabilitation of young people in the institution, while protecting them from punishment, retribution and stigmatization. However, a lack of successful treatment for young people could be used to support the use of more retributive, proportionality-based approaches to disposition.

\section{Methodology}

Qualitative interviews were conducted involving young offenders and correctional staff selected from two juvenile approved schools. The aim was primarily to explore the benefits of vocational education and training in juvenile approved schools from multiple perspectives. Using a purposive sampling technique, a total of 24 participants comprising 16 young offenders and eight correctional staff were selected for qualitative interviews. The sample for young offenders comprised eight males offenders and eight females offenders aged between 12 to 21 years old, with an average of 15.6 years old. All of young offenders reported to be sentenced multiple times. Half of them reported to be sentenced more than two years and half reported less than that. Their convictions ranged from property crimes, drug-related activities to status offences. Overall, participants were diverse in background information.

Ethical approval for the study was granted by the University Ethics Committee (UEC), University of Strathclyde, Scotland (UEC14/40). Also, the permission to conduct the study in two correctional facilities was supported by the Malaysian Economic Planning Unit and approved by the Department of Social Welfare Malaysia. Two juvenile approved schools were approached in different manners at particular periods of time. All participants in each institution were available at the time of the study invited to participate. A script containing detailed consent statement information was verbally explained to participants. The interviews were then conducted individually. The interviews were conducted in a communal area of the institutions. The anonymity and the voluntary nature of the participation were guaranteed. The thematic analysis method was used for analysing and interpreting qualitative data.

\section{Results}

All participants reported to enrol in vocational education and training in the institutions. Five female offenders reported to enrol in tailoring class and three reported to enrol in baking class. Meanwhile, all male offenders reported to enrol in carpentry, craft and electrical wiring classes. Majority participants hold more positive beliefs about vocational education and training that the institutions made available. Most of them seemed to believe that vocational education produce 
Vol. 10, No. 1, 2021, E-ISSN: 2226-6348 @ 2021 HRMARS

benefits for young offenders and it helps to reduce their potential to reoffending. Based on the qualitative findings, four themes about the benefits of vocational education and training have emerged (see Table 1).

Table 1 Themes and quotes of vocational education benefits

\begin{tabular}{l|l}
\hline Themes & Quotes Examples \\
\hline Positive adjustment & 'In here I join bakery classes. I like bakery, even before I came \\
& here. That's the only things make us happy in here. The class \\
start from Monday to Thursday for two or three hours every
\end{tabular}
day (...) I hope we get more time to attend bakery classes.'

(Lana, 15, female)

'Many of us join vocational classes. Because we didn't do well at school. Many of them left school. (...) I join carpentry class. They (staff) sign me for that class. I just follow. But, I enjoy this so much. The only thing make me happy to stay here. I feel like I am in school not prison.'

(Jamal, 17, male)

Rehabilitative effects

'We didn't really get a counselling session. I maybe got twice since I came here. I have been here for two years. But, I don't mind. Joining the class (vocational training) is like a treatment. I feel like I was doing something good to myself.'

(Nora, 15, female)

'Being here makes me a better person. Not because this institution. Not because the staff. At least I can control myself. I can join vocational classes. I can do it every day. It makes me feel useful being in this place. In the class, sometimes you have to build somethings. It is like a treatment. I feel peace. You feel useful.'

(Omar, 17, male)

Positive transition to society

'It is good to gain all these skills. I can be a tailor when I get released. These days tailors can easily make money. I can work from home. (...) All I want now is to get out from here. Start new life. I can earn money from sewing clothes. I hope I can be part of a community.'

(Mina, 16, female) 'I join electrical classes (electrical wiring training). This class is good for me. It prepares me before I get released. I get the skills. I can use my skills to get a job. My teacher said it is easy to get a job with this wiring skills. (...) I know I can do better 
outside. Being in this institution is nothing. I get so bored every day. But, I learn new skills in here. I can use my wiring skills to get a job. People will accept me.'

(Remy, 16, male)

Improve self-esteem

'I join entrepreneur program. Sometimes they bring me outside to meet people. They brought me once to the event at the University. They thought me how to talk to the people. I feel so confident. I feel I will be okay when I get released. I got this chance since I came here. I am more like a human now.'

(Mila, 17, male)

'For 2 weeks I didn't go to the class. It was cancelled so many times. We should have a class every day. At least every week. Staff told us it's because there's no equipment. When I go to the class I feel so confident. I always ask questions to the teacher. He said I am a good student. It makes me feel worthy. I feel I am ready to get released.'

(Yogi, 16, male).

First, some young offenders agreed that vocational education contributes to positive institutional adjustment. Some of them seemed to agree that positive adjustment lead to compliance behaviour and increase motivation to rehabilitation process in the institutions. Majority young offenders agreed that institutional routine is unpleasant and discomforting. For some offenders, nonetheless, joining classes in the institutions might distract them from the immediate environment because activities can be functional, or have anesthetizing effects. As such, it maximizes the pleasant stimulus. Lana and Jamal stressed that vocational trainings are relevant to a pleasant stimulation, and to be realistic, this helps them to cope with the institution life and facilitates social control. They also agreed that attending classes and trainings contribute to positive adjustment and help them to perceive time faster. Thus, if time in institution seems short in retrospect, the deterrent effect of imprisonment is reduced (see Toch, 1977). In particular, this could be an effort to solve a variety of problems and conflicts of which adjustment to imprisonment is one.

Secondly, young offenders seemed to agree that vocational education and training produces rehabilitative effects. It is believed that vocational education is effectively promote physical and mental well-being among young offenders in the institutions. Vocational education provides chances to young offenders to not only learn or develop new skills but also to complete tasks, work in a team, make decisions and solve problems. In the class, young offenders are encouraged to positively interact with one another, and this develops their social skills and improves individual functions in everyday life. A positive classroom environment also contribute to a positive institutional environment. Indeed, a good institutional climate may improve the outcomes of rehabilitation programs (Liebling, 2012). 
Thirdly, young offenders agreed that vocational education contributes to positive transition to society. Either young or adult offenders always face challenges to reintegrate into family and society after their release. Therefore, treatments provided in the institutions must gear towards preparing young offenders from the very instant they step into the school for their ultimate return to their family and society. Vocational education provides young offenders with job skills and career readiness that can help them to get a job upon released. Having a job helps them to successful reintegrate with society by increasing their social support, maintaining socioeconomic status, and improving their mental health well-being (Osborn \& Belle, 2018). In fact, being employed reduce reoffending. Studies reveal strong association between unemployment and reoffending (Newton et al., 2018).

Lastly, young offenders agreed that vocational education can greatly influence their self-esteem. The central idea of self-esteem consists of two important concepts; positive feelings towards oneself and self- confidence (Buss, 1995). Many young offenders held beliefs about the ways in which people devalue and react negatively to them. This stereotypical effect results in shame, low self-confidence and low self-worth. Learning practical skills, through vocational education, can have recreational effects. It involves individuals, small groups, teams or whole communities and are relevant to people of all different ages, abilities and levels of skill. Recreation has many benefits, including to improve the health and well-being of individuals and to contribute to the empowerment of individuals. Recreational activities are specified to have positive effect on increasing the self-esteem level and decreasing loneliness level of the offenders (Basaran, 2016). Indeed, vocational education is associated with one's feeling of worth and confidence in one's own abilities.

\section{Discussion \& Conclusion}

Majority young offenders hold more positive beliefs about vocational education and training that the institutions made available. The term vocational education is general and includes every forms of education that aims at the acquisition of skills or qualifications related to a certain profession, art or employment (Williams, 2017). Most of young offenders believed that vocational education helps to reduce their potential to reoffending at least in four circumstances, including positive adjustment, rehabilitative effects, positive transition to society and improve self-esteem. Scholars support these findings by asserting that vocational education and training have a rehabilitative potential (Okwelle \& Deebom, 2018; Newton et al., 2018; Azam et al., 2021; Esa et al., 2017; Khemtong, 2017). It can improve an offender's health, skills and interest. Some scholars agree that rehabilitation of young offenders succeeds through vocational education. Through vocational education, offenders may understand their purpose in life, and this is important for offenders to be truly rehabilitated (Morris, 1995).

The treatment and education are important elements in the institutions that helps offenders to address their offending behaviour and helps offenders with progression. In the institutions, treatment and education is served for the purpose of rehabilitation. Rehabilitation is one of the most important purposes of incarceration that is deeply rooted in the idea that offenders could be return to the free world as law abiding citizen (Phelps, 2011). To achieve this, institutions are 
responsible to provide appropriate treatments and education for offenders. Therefore, offenders are entitled to basic needs and adequate facilities for their own wellbeing in the institutions. They are also entitled to access to treatments, educational programs and activities that related to behavioural and cognitive improvement. All these aspects are believed to help in offenders' rehabilitation. Nonetheless, overcrowding may result in denying offender's access to meaningful educational programs or services available in the institutions. Programs and jobs for offenders may be a valuable tool to promote a better adjustment to prison and have the potential to create safer prison environments for prison communities (Wooldredge \& Steiner, 2015). However, investment in programs and jobs may be ineffective in reducing misconduct levels in the institutions where there are higher populations, as proportionately fewer inmates will have access to these services. In addition, some institutions invest less in programs for inmates due to excessive workloads. Officers and staff in crowded facilities face not just threats to their own safety but heavy burdens in relation to their work. A combination of understaffing and extreme crowding has played a role in the amount of stress, staff turnover, and the health risks. For this reason, staff are less likely to operate any program for offenders. Also, the lack of trained and skilled staff resulted in the absence of a meaningful educational program.

To conclude, placing young offenders in the correctional institutions might promote positive outcomes (Bales \& Piquero, 2012). This study supports that vocational education serves positive outcomes for young offenders. It becomes a quintessential part of most correctional programs. Nonetheless, some juvenile approved schools in Malaysia provide inadequate vocational education and training. In fact, some institutions have failed to provide vocational education for young offenders. Some young offenders are very critical of the daily operations in the institutions. Inadequate vocational training make offenders perceive the treatments received in the institutions is unfair, improper and inconsistent. Some young offenders feel that dealing with these inconsistent procedures is fraught with difficulties. The difficulties of daily operations lead to an unwillingness to comply with criminal justice authority, including policing, judicial systems, and corrections (Tyler, 2006). This interrupts rehabilitation process.

Young offenders have a history of unstable employment and they are often lack of job skills. Studies found that unemployment is associated with offending and reoffending (Newton et al., 2018). As a response, correctional institutions provide vocational education and training to young offenders in the approved schools in order to assist them in getting employment after release. Employment after release facilitates young offenders to success reintegration into family and society and ultimately reducing repeat offending. Therefore, this study urges Malaysian juvenile justice system in order to improve policies and programs pertaining vocational education for young offenders. The system needs to develop a holistic framework for vocational education so that offenders who receive vocational training may succeed in the job market of the communities they live after release. The aim of Malaysian correctional service is not to punish and deprive the liberty of young offenders, but to reform, rehabilitate and reintegrate. In fact, young offenders have a right to receive proper treatment and education in juvenile approved schools. 
INTERNATIONAL JOURNAL OF ACADEMIC RESEARCH IN PROGRESSIVE EDUCATION AND

DEVELOPMENT

Vol. 10, No. 1, 2021, E-ISSN: 2226-6348 @ 2021 HRMARS

\section{References}

Azam, S. B. M., Bakar, S. H. A., Yusoff, J. Z. M., \& Rauf, S. H. A. (2021). A case study on academic and vocational training for child offenders undergoing a multisystemic therapy-based rehabilitation order in Malaysia. Children and Youth Services Review, 122, 105911.

Bales, W. D., \& Piquero, A. R. (2012). Assessing the impact of imprisonment on recidivism. Journal of Experimental Criminology, 8(1), 71-101.

Basaran, Z. (2016). The Effect of Recreational Activities on the Self-Esteem and Loneliness Level of the Prisoners as an Alternative Education. Universal journal of educational research, 4(5), 1080-1088

Bee, T. G. (2002). Institutional treatment management of organizations for juvenile offenders in Malaysia. UNAFEI Annual Report, 59, 203-219.

Bode, J. (2019). Juvenile punishment system in view of the need for education and reintegration. European Journal of Interdisciplinary Studies, 5(3), 21-29.

Department of Statistics Malaysia. (2019). Children statistics, Malaysia. Retrieved from, https://www.dosm.gov.my/v1/index.php?r=column/pdfPrev\&id=TVY4ZDdTeFJnMFQxWjd Fc1dDZEhOZz09

Esa, A., Salleh, B. M., \& Mohamad, N. H. (2017). Integrating vocational training in culinary arts and Islamic studies at Juvenile Rehabilitation Centres: Malaysian experience. Journal of Technical Education and Training, 9(1), 100-112.

Khemthong, S. (2017). The Effect of Occupational Therapy on Volitional and Vocational Skills in the Thai Juvenile Justice System. International Journal of Child Development and Mental Health, 5(2), 40-44.

Newton, D., Day, A., Giles, M., Wodak, J., Graffam, J., \& Baldry, E. (2018). The impact of vocational education and training programs on recidivism: A systematic review of current experimental evidence. International Journal of Offender Therapy \& Comparative Criminology, 62(1), 187-207.

Okwelle, P. C., \& Deebom, M. T. (2018). Status of training facilities in vocational education training programmes in Nigerian prisons in Rivers State. Asian Journal of Science and Technology, 9(1), 7430-7436.

Osborn, D. S., \& Belle, J. G. (2019). Preparing juvenile offenders for college and career readiness: A cognitive information processing approach. Journal of Educational and Psychological Consultation, 29(3), 283-313.

Phelps, M. S. (2011). Rehabilitation in the punitive era: the gap between rhetoric and reality in US prison programs. Law \& Society Review, 45(1), 33-68.

Tyler, T. R. (2006). Restorative justice and procedural justice: dealing with rule breaking. Journal of Social Issues, 62(2), 307-326.

UNICEF. (2013). The Malaysian Juvenile Justice System: as study of mechanism for handling children in conflict with the law. Retrieved from, http://www.unicef.org/malaysia/The_Msian_Juvenile_Justice_System_Nov_13_R2.pdf

Williams, Y. (2017). Vocational Programs for Juveniles. The Encyclopedia of Corrections, 13. Wooldredge, J., \& Steiner, B. (2015). A macro-level perspective on prison inmate deviance. Punishment \& Society, 17(2), 230-257. 